\title{
トンボの翅の受動的な変形が空力特性に与える影響
}

中 尚義*1, 橋本 巨*2

\section{The effect of passive deformation of dragonfly wing on aerodynamic characteristics}

\author{
Hisayoshi NAKA $^{* 1}$ and Hiromu HASHIMOTO ${ }^{* 2}$ \\ ${ }^{* 1}$ Graduate School of Science and Technology, Tokai University \\ 4-1-1 Kitakaname, Hiratsuka-shi, Kanagawa 259-1292, Japan \\ ${ }^{* 2}$ Department of Mechanical Engineering, Tokai University \\ 4-1-1 Kitakaname, Hiratsuka-shi, Kanagawa 259-1292, Japan
}

Received 13 April 2015

\begin{abstract}
Dragonflies can perform both of gliding and flapping flight and have high maneuverability in spite of small-size. The aim of this study is to develop Micro Air Vehicle (MAV) based on the flight of dragonfly. The characteristics of wings are very important for development of MAV. Dragonfly wing is easy to be passively deformed in the tip side from the nodus in flapping flight, and thereby, aerodynamic force is generated effectively. In this study, the effect of passive deformation of wing on aerodynamic force was investigated using fluid-structure interaction analysis to develop the artificial wing suitable for dragonfly-like MAV. In this study, aerodynamic characteristics of wings in the gliding flight and aerodynamic force generated in flapping flight are numerically analyzed. In this analysis, nodus wing models, which can deform passively, and rigid wing model, which cannot deform, are used. Nodus wing model imitates the nodus structure; the tip side of this model is free to rotate around leading edge. As a result of gliding flight, the lift coefficient of the nodus wing was lower in low-angle of attack and was higher in high-angle of attack, compared to rigid wing. Moreover, the more flexible wings are, the more change. The gliding flight is low-angle of attack usually. Therefore, flexible wing is less suitable for the gliding flight than inflexible wing. As a result of flapping flight, the nodus wing made drag force generated during down stroke lower compared with the rigid wing. However, thrust forces generated during up stroke in both wings were the same. Therefore, flexible wing is more suitable for the flapping flight than inflexible wing. The wings of dragonfly-like MAV need to appropriate level of flexibility to upgrade the performance in both case of gliding and flapping flight.
\end{abstract}

Key words : Biomimetics, Insect flight, Dragonfly, Wing, Deformation, Aerodynamics, Lift force, Drag force, Fluid-structure interaction

\section{1. 緒言}

自然界の生物は長い歴史を経てそれぞれの環境に適合するように最適化された優れた機能や構造を有している， このような生物の多様な生態に注目し，その特性を人工物に応用寸るバイオミメティクスと呼ばれる研究が多く の研究機関で行われている. 数ある生物種の中でも, 昆虫は世界の様々な気候や環境に適応した多様な種が存在 することからその特性が注目されている. 特に注目すべき昆虫としてハエやトンボといった飛翔昆虫が挙げられ る. 小型の飛翔体には寸法効果により強い粘性力が働くため, 固定翼や回転翼といった従来の飛行形式では飛行 が困難となる。しかしながら，飛翔昆虫は非常に小型でありながら自在な飛翔を行っている．本研究ではそうし た昆虫の飛翔に着目し，それらをモデルとした Micro Air Vehicle（MAV：超小型飛翔体）を開発することを目指 している. しかし, 昆虫の飛翔については未解明の部分が多く, その飛翔メカニズムの解明が求められている.

\footnotetext{
No.15-00209 [DOI:10.1299/transjsme.15-00209], J-STAGE Advance Publication date : 13 January, 2016

*1 正員, 東海大学大学院 総合理工学研究科（T259-1292 神奈川県平塚市北金目 4-1-1）

*2 正員, フェロー, 東海大学 工学部

E-mail of corresponding author: hiromu@keyaki.cc.u-tokai.ac.jp
} 
飛翔昆虫の中でも，トンボは特に優れた飛翔性能を有していることで知られている．トンボは羽ばたき飛翔に より急加速や急旋回，ホバリングなど多彩な運動が可能な高い運動性能を実現していることに加え，滑空による エネルギー消費の少ない飛翔が可能で，長距離の “渡り”が可能な種も存在する．こうしたトンボの飛翔は広範 囲の移動と狭小な空間での探索が求められる MAV のモデルに適していると考えられることから, MAV に応用す るべく, その飛翔メカニズムについて研究が行われている (Azuma and Watanabe, 1988, 橋本, 石本, 1997, Dickinson et al., 1999, 伊賀, 橋本, 2007).

これまでの研究で，トンボの高度な飛翔にはその翅の特性が重要であることが明らかとなってきている．トン ボの翅は薄く柔軟であり, 飛翔時に受動的に変形することが知られている（Sunada et al., 1998, 藤井, 大熊, 2004, Chen et al., 2008, Jongerius and Lentink, 2010)。そのため, 羽ばたき時に翅が受動的に変形することで大きな浮上力 が生成されることが報告されている (Nakata and Liu, 2012).さらに, 著者らのこれまでの研究でトンボの翅は結 節と呼ばれる翅脈構造が翅の変形特性に大きく影響していることが初めて明らかにされている（Naka and Hashimoto, 2015)。結節はトンボに固有の翅脈構造で, 翅の前縁部中央付近に存在する. トンボの翅は結節部分か ら先がねじれ変形をしやすくなっており，羽ばたき時に先端部が受動的に変形することで空気力の生成効率が向 上している．したがって，トンボ型 MAV に搭載する人工翅を設計する際には結節の機能を含めた翅の変形特性 についても考慮する必要がある. しかし，これまでの研究では翅が受動的に変形する場合に性能が向上すること を述べるにとどまっており, 受動的な変形が翅の空力特性にどの程度影響するのか, どのような変形が最適なの かといったことは明らかでない，また，トンボ型 MAV の場合には滑空と羽ばたき飛翔の両方に適した人工翅を 設計する必要があるが, 滑空時の性能については研究が行われておらず, 未だ不明瞭な点が多い. トンボ型 MAV に適した人工翅を設計するためには, 滑空時と羽ばたき飛翔時の両方で翅の受動的な変形の違いが空力特性に与 える影響について明らかにする必要がある. 本研究では, 結節の機能に着目してトンボ型 MAV に最適な翅を作 製することを目的としている，その第一歩として，流体一構造連成解析によりトンボの翅の結節による変形を模 擬した翅モデルを用いて滑空時および习习习゙゙たき時の空力特性について検討したので報告する.

\section{2. 数值解析}

数值計算に際して, 翅の変形を求める構造解析には ANSYS Mechanical を, 流れにより翅にかかる圧力を求め る流体解析には ANSYS Fluent を用いる. 構造解析と流体解析の連成では, 流体と構造の境界面における变位と 圧力を構造解析と流体解析で相互に転送する弱連成解析を行う.

\section{$2 \cdot 1$ 結節翅モデル}

本研究では，前述した結節による変形の特徴を模擬したモデル（結節翅モデル）を使用する. 図 1 にトンボの 翅とそれに対応した結節翅モデルを示す．結節翅モデルは円柱状の前縁部と板状の膜部で構成される．トンボの 翅は結節より根元側では変形しにくいのに対し, 結節より先端側は前縁部からねじれるように変形をする（Naka and Hashimoto, 2015)。この特徵的な変形を模擬するため, 結節翅モデルでは前縁部を剛体, 膜部を弾性体と仮定 し, 結節より先端側と根元側で膜部前縁側の境界条件を変更した. 膜部前縁側のある位置に結節として切久きを 入れ, 切久きより根元側では境界条件を完全固定（6自由度を拘束）とし, 先端側では前縁部を中心とした回転 のみ自由（前縁部軸方向の回転 1 自由度のみ自由，その他 5 自由度を拘束）とすることで, 先端側において膜部 が前縁部を中心としたねじれ変形をしやすくしている. 膜部の寸法はギンヤンマの後翅と同一の長さとアスペク 卜比となるよう, 翼幅 $50 \mathrm{~mm}$, 翼弦長 $12 \mathrm{~mm}$ に設定している．膜部の材質は，前報（Naka and Hashimoto, 2015） の実験でトンボの翅に近い変形量を達成した人工翅と同様に膜厚さ $50 \mu \mathrm{m}$ の PET フィルム（ヤング率 $E=5.18 \times$ $\left.10^{9} \mathrm{~Pa}\right)$ とした. また，本研究では MAVの人工翅を設計することを目的として人工翅における変形の影響を検討 するため, トンボの翅の平面形状を模擬せず単純な四角形状のモデルとした.

翅の受動的な変形の違いが空力特性に与える影響を検討するため, 図 2 に示すように結節（Nodus）の位置が 異なる 2 種類の結節翅モデルと変形をしない剛体翅モデルの 3 種類の翅モデルについて比較を行う. トンボの翅 と同様に結節を中央（根元から $25 \mathrm{~mm}$ の位置）とした結節翅（中央），結節を根元付近（根元から $2 \mathrm{~mm}$ の位置） に想定した結節翅 (根元), 先端側・根元側ともに完全固定し膜部を剛体と仮定した剛体翅の 3 種類である. 結節 


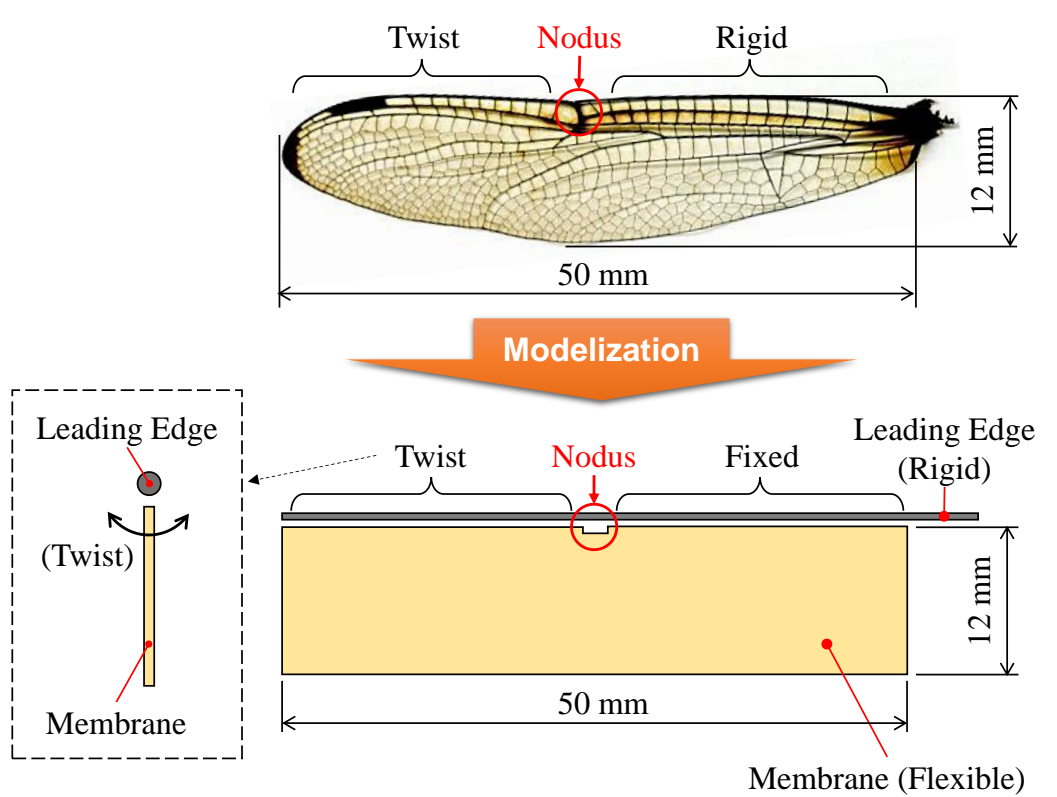

Fig. 1 Overview of Nodus wing model. The nodus wing model mimics the deformation characteristics of dragonfly wings that deformation is large in tip side of wing. The nodus wing consists of leading edge and membrane. The membrane is fixed to leading edge in the base side. On the other hands, the membrane is not fixed to leading edge and can rotate around leading edge in the tip side.

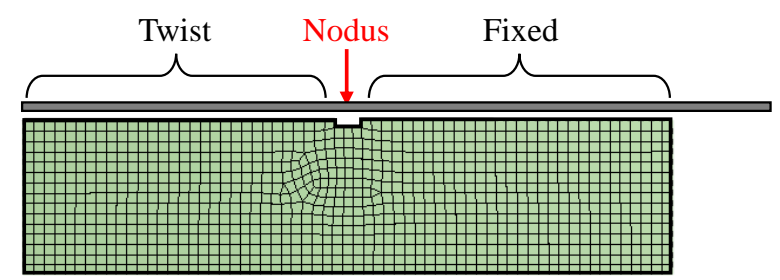

(a) Nodus wing (Center)

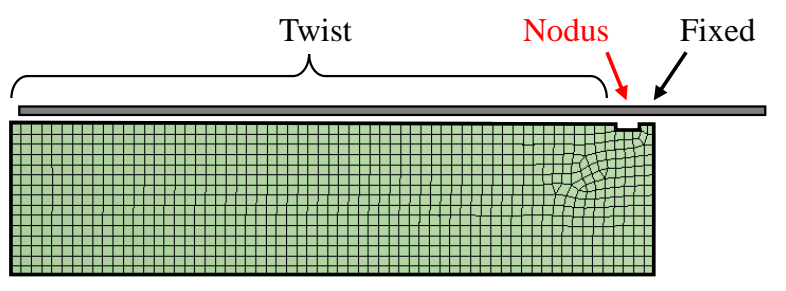

(b) Nodus wing (Base)

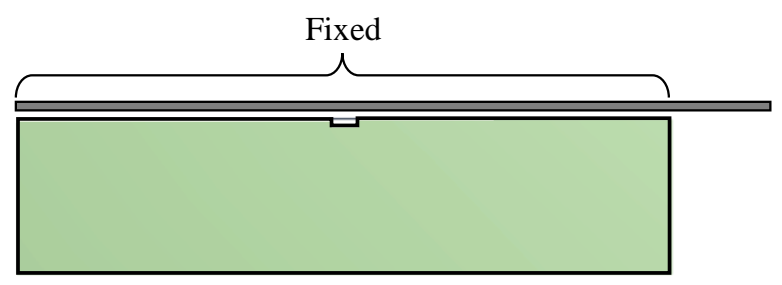

(c) Rigid wing

Fig. 2 Three types of wing models. The two types of nodus wing models differ in the location of nodus. Rigid wing is not able to deform, and therefore the fluid analysis is conducted only.

翅モデルの要素形状は六面体, 要素数は約 2,500 である. 図 2 を見ると結節の付近で要素形状が変化しているが, 要素のサイズおよび形状についてはより細かくして形状の変化が無い場合と結果に差が無いことを確認している. なお，剛体翅では流体解析のみで解析を行った。

\section{$2 \cdot 2$ 滑空時の空力特性解析}

前述の翅モデルを用いて滑空を模擬した定常流中における揚力係数および抗力係数を求めた. 図 3 に解析領域 を, 表 1 に解析条件を示す. 解析領域として長さ $400 \mathrm{~mm}$, 幅 $300 \mathrm{~mm}$, 高さ $300 \mathrm{~mm}$ の空間を設定し, 前方から $100 \mathrm{~mm}$, 端から $5 \mathrm{~mm}$, 底から $150 \mathrm{~mm}$ のころに翅モデル膜部の端部が位置するように翅モデルを設置した。 左右に翅を広げた滑空状態を想定し翅モデルに近い壁面には境界条件を対称条件とした。その他の面には境界条 
件として前方に流入境界（流速固定）を，反対側に流出境界（圧力固定 : 大気圧）を，上下面および側面に流入 流速と同速度の滑り壁条件を設定した．解析領域の大きさについては，大きさを変えて迎角 $90 \mathrm{deg}$ の解析を試行 し, 結果に変化が無くなる大きさであれば十分であると判断した. 図 4 に幅, 高さを変化させたときの解析の試 行結果を示す. 図から, 幅および高さは $300 \mathrm{~mm}$ と設定している. 解析条件としては, 流体は空気 (密度 $\rho=1.205$ $\left.\mathrm{kg} / \mathrm{m}^{3}\right)$ とし, 乱流モデルには $\mathrm{k}-\varepsilon$ モデルを用いた。流体一構造連成解析では，上記の条件で流体解析を行い，翅 モデル表面における圧力を求め, それを構造解析に転送する。 そして構造解析により求めた翅モデルの変位を流 体解析に転送する．この時の翅モデル周辺のメッシュの変形については，大変形に対応したリメッシング法を適 用した．また，リメッシング法による自動メッシングに対応するため，要素形状は四面体とした．時間ステップ は $1 \times 10^{-3} \mathrm{~s}$ とし，ステップ数は翅の変形が収束し定常状態となる 600 ステップに設定した．迎え角は $0,10,30,50$, 70, $90 \mathrm{deg}$ の 6 通りとした. なお, 本解析における迎え角は翅モデルが変形していない状態での迎え角を表してい る. 流入流速は巡航飛翔を想定した $3 \mathrm{~m} / \mathrm{s}$ と加速時等を想定した $6 \mathrm{~m} / \mathrm{s} の 2$ 通りとした. 上記の条件で解析を行い, 翅モデルにかかる力から次の式で揚力係数 $C_{\mathrm{L}}$ および抗力係数 $C_{\mathrm{D}}$ を求めた.

$$
C_{L}=\frac{2 L}{\rho U^{2} S}
$$

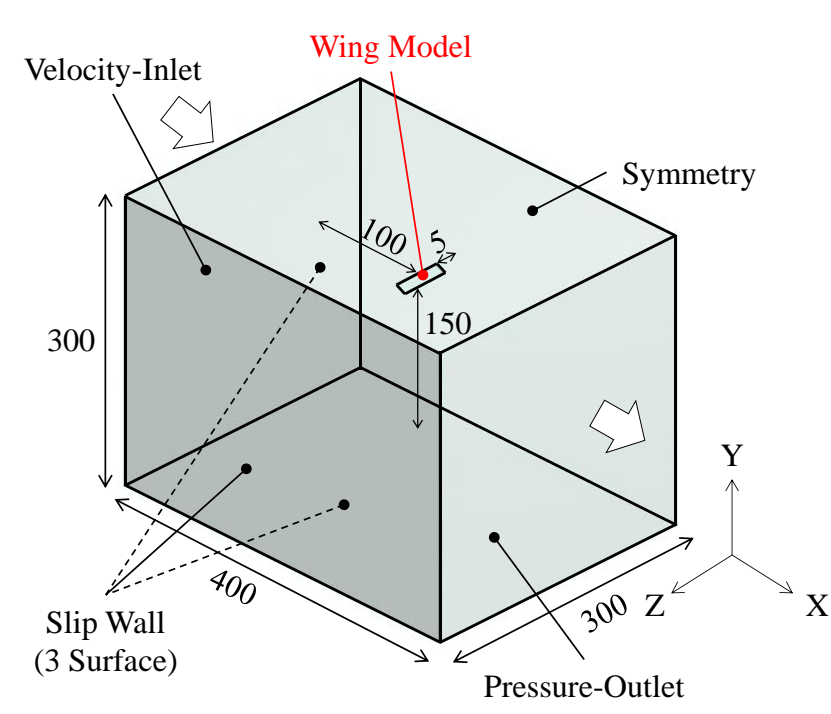

Fig. 3 Analytical area and boundary conditions in gliding flight
Table 1 Calculation condition in gliding flight

\begin{tabular}{|c|c|c|}
\hline \multirow{2}{*}{$\begin{array}{l}\text { Analytical } \\
\text { area }\end{array}$} & $\begin{array}{c}\text { Size of flow } \\
\text { box }\end{array}$ & $400 \times 300 \times 300 \mathrm{~mm}$ \\
\hline & Size of wing & $12 \times 50 \times 0.05 \mathrm{~mm}$ \\
\hline \multirow{2}{*}{$\begin{array}{c}\text { Input } \\
\text { condition }\end{array}$} & Inlet & $3 \mathrm{~m} / \mathrm{s}, 6 \mathrm{~m} / \mathrm{s}$ \\
\hline & Outlet & $0 \mathrm{~Pa}$ \\
\hline \multirow{3}{*}{ Mesh } & Type & Tetrahedron \\
\hline & Cells & About 440,000 \\
\hline & Deformation & Remeshing method \\
\hline \multirow{4}{*}{$\begin{array}{l}\text { Calculation } \\
\text { condition }\end{array}$} & Fluid & Air \\
\hline & $\begin{array}{c}\text { Turbulence } \\
\text { model }\end{array}$ & $\mathrm{k}-\varepsilon$ model \\
\hline & Time step & $1 \times 10^{-3} \mathrm{~s}$ \\
\hline & $\begin{array}{c}\text { Number of } \\
\text { step }\end{array}$ & 600 \\
\hline
\end{tabular}

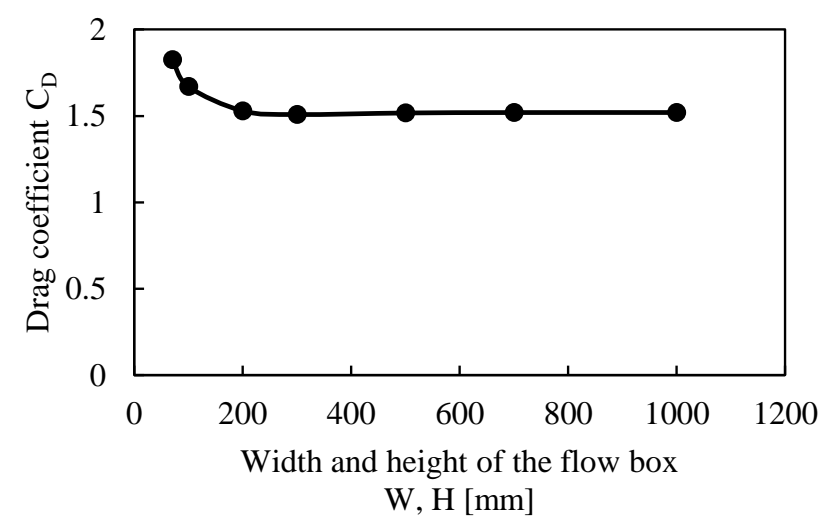

Fig. 4 Relationship of drag coefficient on gliding flight and size of the flow box. When the size of flow box is larger than 300 $\mathrm{mm}$, drag coefficient is constant. Therefore, $300 \mathrm{~mm}$ of the size of flow box is enough for the analysis of gliding flight. 


$$
C_{D}=\frac{2 D}{\rho U^{2} S}
$$

この時, $L$ :揚力 ( $\mathrm{Y}$ 方向の力),$D$ :抗力 (X 方向の力),$\rho$ :空気密度, $U$ :主流流速, $S$ :翼面積である.

\section{$2 \cdot 3$ 羽ばたき時の空力特性解析}

羽ばたき時に翅に生じる揚力および抗力を解析により求めた．図 5 に解析領域を，表 2 に解析条件を示寸．羽 ばたきは円弧運動であるため, それに合わせ解析領域を長さ $150 \mathrm{~mm}$, 半径 $120 \mathrm{~mm}$ の半円柱の上下端を羽ばたき の角度に合わせて $30 \mathrm{deg}$ で切断した形状に設定した. 解析領域の大きさについては, 滑空時の解析と同様にこれ 以上大きくしても結果に変化が無いことを確認している. 翅モデルは円の中心で前方から $50 \mathrm{~mm}$ の位置を回転中 心として羽ばたき運動を行うものとし，また回転中心から半径方向に $5 \mathrm{~mm}$ 離れたところに翅モデル膜部の端部 が位置するように翅モデルを配置した. 左右対称に羽ばたくことを想定し, 側面には境界条件を対称条件とした. その他境界条件として, 前方の面に流入境界 (流速固定), 反対側に流出境界 (圧力固定 : 大気圧),

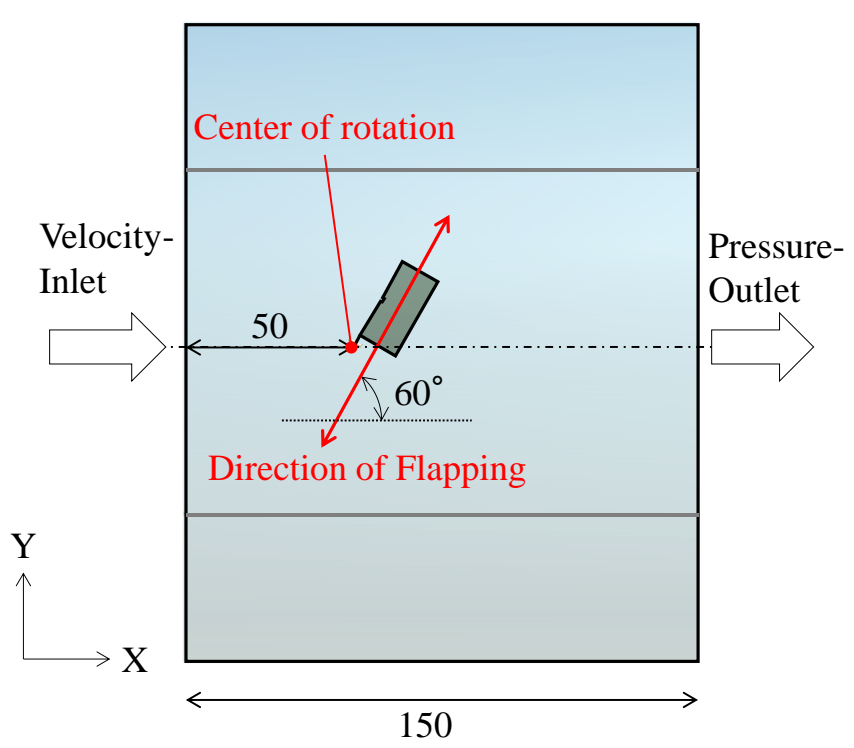

(a) Side view

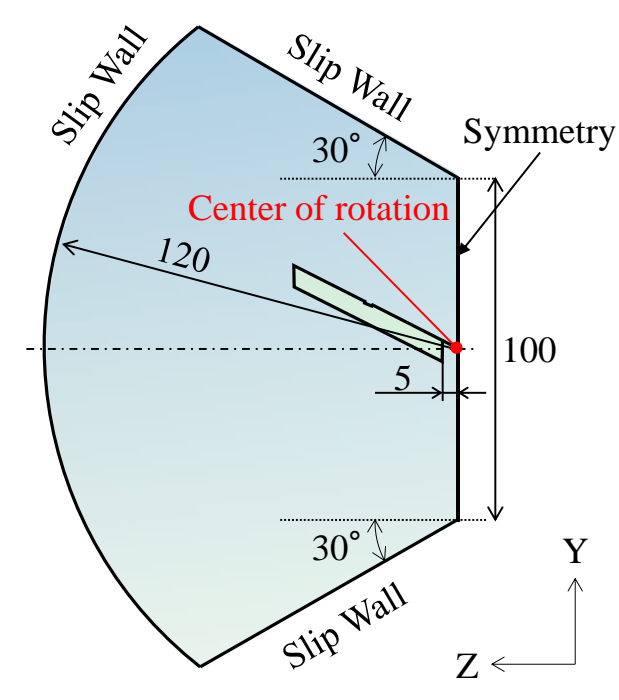

(b) Back view

Fig. 5 Analytical area and boundary conditions in flapping flight

Table 2 Calculation condition in flapping flight

\begin{tabular}{c|c|c}
\hline \multirow{2}{*}{ Analytical area } & Size of flow box & $150 \times 120 \times 200 \mathrm{~mm}$ \\
\cline { 2 - 3 } & Size of wing & $12 \times 50 \times 0.05 \mathrm{~mm}$ \\
\hline \multirow{2}{*}{ Input condition } & Inlet & $3 \mathrm{~m} / \mathrm{s}$ \\
\cline { 2 - 3 } & Outlet & $0 \mathrm{~Pa}$ \\
\hline \multirow{3}{*}{ Mesh } & Type & Tetrahedron \\
\cline { 2 - 3 } & Cells & About 480,000 \\
\cline { 2 - 3 } & Deformation & Remeshing method \\
\hline \multirow{4}{*}{ Calculation condition } & Fluid & Air \\
\cline { 2 - 3 } & Turbulence model & $\mathrm{k}-\varepsilon$ model \\
\cline { 2 - 3 } & Time step & $2.5 \times 10^{-5} \mathrm{~s}$ \\
\cline { 2 - 3 } & Number of step & 4000 \\
\hline
\end{tabular}


残りの面は流入流速と同速度の滑り壁条件を設定した，翅の変形によるメッシュの変形については，滑空時の解 析と同様にリメッシング法を適用し，要素形状は四面体とした，羽ばたき運動については，トンボの羽ばたきは 水平面に対し垂直ではなく角度を持つため, 本解析においても図 5(a)に示寸ように水平面に対し $60 \mathrm{deg}$ の角度で 羽ばたくものとした. 図 6 に設定した羽ばたき運動を示す.トンボの前進飛翔を参考に, 羽ばたき運動は正弦波, 羽ばたき角度は上下に $30 \mathrm{deg}$ ずつの振幅 $60 \mathrm{deg}$, 羽ばたき周波数は $30 \mathrm{~Hz}$ とした．また，フラッピング角度 $\Psi=$ $30 \mathrm{deg}$ となるところを初期位置（ $T=0 ）$ とした．なお，実際のトンボはフェザリングと呼ばれる翅を㸚じる運動 も併せて行うが，本解析では翅の変形とフラッピングの関係についてのみ検討寸るためフェザリング運動は行わ ないものとした，そのため，翅モデルは羽ばたき方向に直角 $(90 \mathrm{deg})$ となり, 主流に対する翅の迎え角は $30 \mathrm{deg}$ で一定となっている. 流体は空気 (密度 $\rho=1.205 \mathrm{~kg} / \mathrm{m}^{3}$ ), 乱流モデルは $\mathrm{k}-\varepsilon$ モデルとし, 流入流速はトンボの前 進飛翔時の一般的な前進速度である $3 \mathrm{~m} / \mathrm{s}$ とした. 時間ステップは $2.5 \times 10^{-5} \mathrm{~s}$ とし，ステップ数は羽ばたき 3 周期 分となる 4000 ステップに設定した. 羽ばたきの解析では揚力・抗力が変動することから, 定常的な係数として算 出せずに各時刻における翅の表面にかかる力から揚力（Y 方向の力）と抗力（X 方向の力）を求めるものとした.

\section{3. 解析結果}

\section{$3 \cdot 1$ 滑空時の解析結果}

図 7 に流入流速 $3 \mathrm{~m} / \mathrm{s}$ の場合の各迎え角における揚力係数・抗力係数の解析結果を示寸. 剛体翅の揚力係数に ついて, 先行研究（酒井, 橋本, 2014）の実験で求められた矩形形状平板翅の揚力係数と近しい結果となってお り, 妥当な解析結果であるといえる. 揚力係数を結節翅と剛体翅で比較すると, 結節翅では剛体翅と比べ $30 \mathrm{deg}$

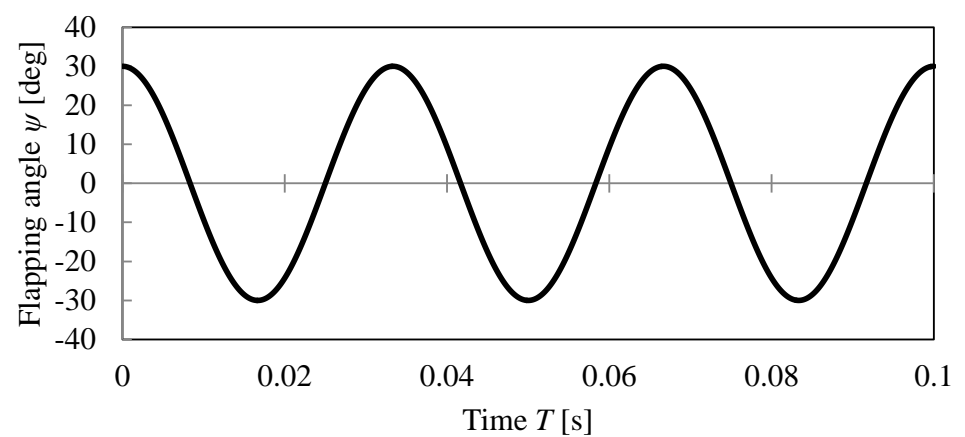

Fig. 6 Flapping motion of the wing model. Flapping motion is sine wave, and flapping angle is from -30 to +30 deg. Flapping frequency is $30 \mathrm{~Hz}$.

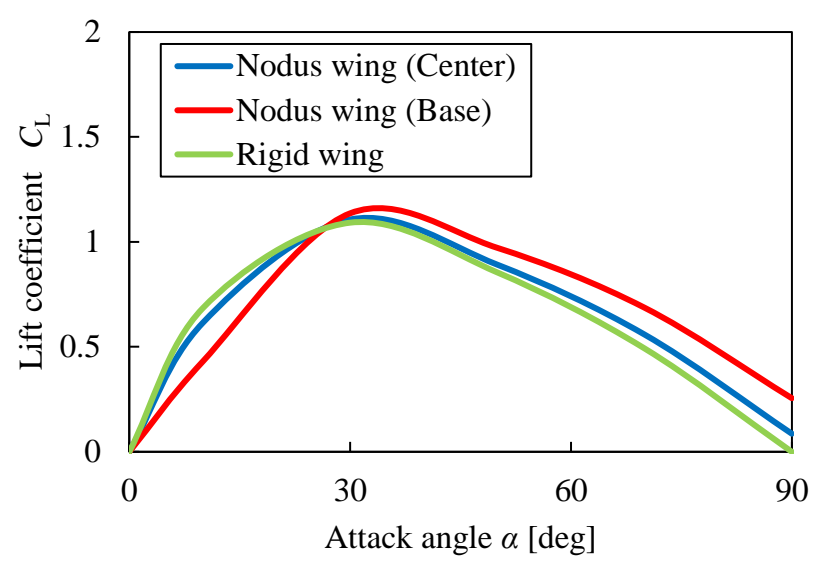

(a) Lift coefficient

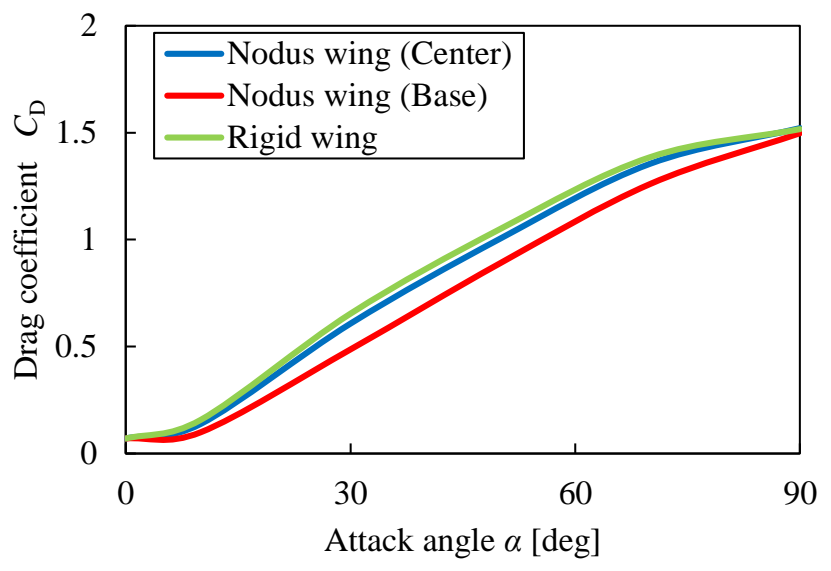

(b) Drag coefficient

Fig. 7 Analytical results of lift and thrust coefficient on gliding flight in case of $U=3 \mathrm{~m} / \mathrm{s}$. Nodus wings decrease drag coefficient compared to rigid wing. When $a<30 \mathrm{deg}$, nodus wings decrease lift coefficient compared to rigid wing. When $a>30 \mathrm{deg}$, nodus wings increase lift coefficient compared to rigid wing. Such changes are larger in nodus wing (base) compared to nodus wing (center). 
以下の小さい迎え角では揚力係数が低下寸るのに対し，30 deg 以上の大きい迎え角では揚力係数が増大した．抗 力係数は全ての迎え角で結節翅の方が低くなった．また，結節翅（中央）と結節翅（根元）で比較すると，結節 翅（根元）の方が大きく変化した. 図 8 に流入流速 $3 \mathrm{~m} / \mathrm{s}$, 迎え角 $30 \mathrm{deg}$ の時の結節翅の変形の様子を示寸. 翅 の色はその位置の変形前からの変位量を表し, 図中の破線は変形前の先端部の位置を示している. 図より，風の 抵抗により翅が受動的に変形し，特に先端部で大きく変形していることが確認できる．表 3 に各迎え角における 先端部の変形角度を示寸，迎え角が大きくなるに応じて変形角度も増加し，結節翅（中央）では最大で $3.5 \mathrm{deg}$, 結節翅（根元）では最大で $10.3 \mathrm{deg}$ の変形を起こした．このように風の抵抗により翅が受動的な変形をすること で前面投影面積が減少し，抗力係数が減少した．また，翅が変形することで実質の迎え角が減少するとみなせる ため, 揚力係数がピークとなる迎え角 $30 \mathrm{deg}$ 以下では揚力係数が剛体翅と比べ低くなったが, ピークを越えた迎 え角 $30 \mathrm{deg}$ 以上では剛体翅と比べ高くなったと考えられる．また，結節翅（中央）よりも結節翅（根元）の変形 量が大きかったために揚力係数および抗力係数の変化が大きくなった.一般的に滑空飛翔では 10〜20 deg 程度の 小迎角となることから迎え角 $10 \mathrm{deg}$ で揚力係数 $C_{\mathrm{L}}$ および抗力係数 $C_{\mathrm{D}}$ を比較する. 表 4 に揚力係数 $C_{\mathrm{L}}$ および抗 力係数 $C_{\mathrm{D}}$ とそれらから算出した揚抗比 $\mathrm{L} / \mathrm{D}$ を示す. 剛体翅は $C_{\mathrm{L}}=0.685, C_{\mathrm{D}}=0.157$ であるのに対し, 結節翅 (中 央）は $C_{\mathrm{L}}=0.615, C_{\mathrm{D}}=0.138$ とどちらも $10 \%$ 程度減少，結節翅（根元）では $C_{\mathrm{L}}=0.431, C_{\mathrm{D}}=0.099$ と $37 \%$ 程度

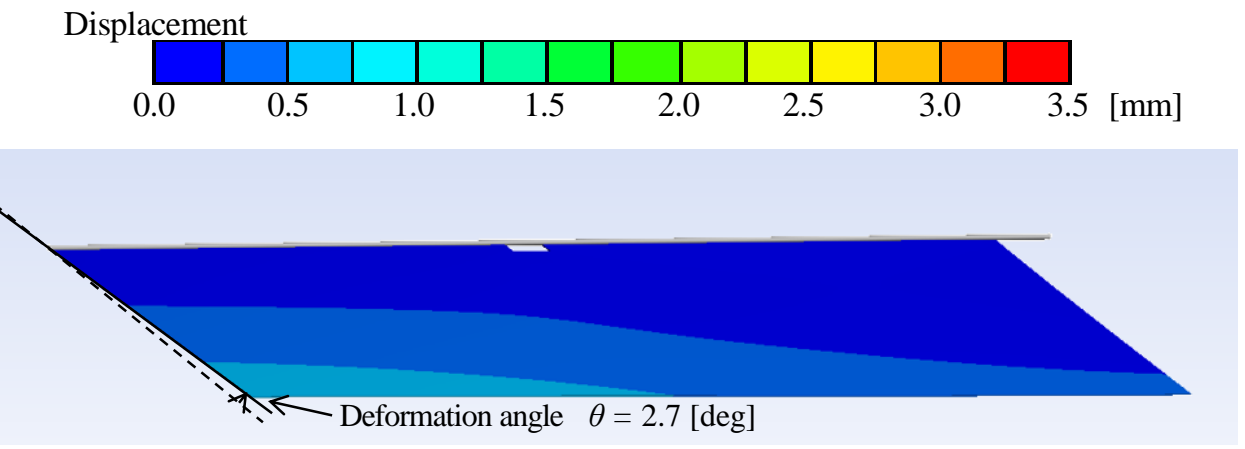

(a) Deformation of Nodus wing (Center) $(\alpha=30 \mathrm{deg})$

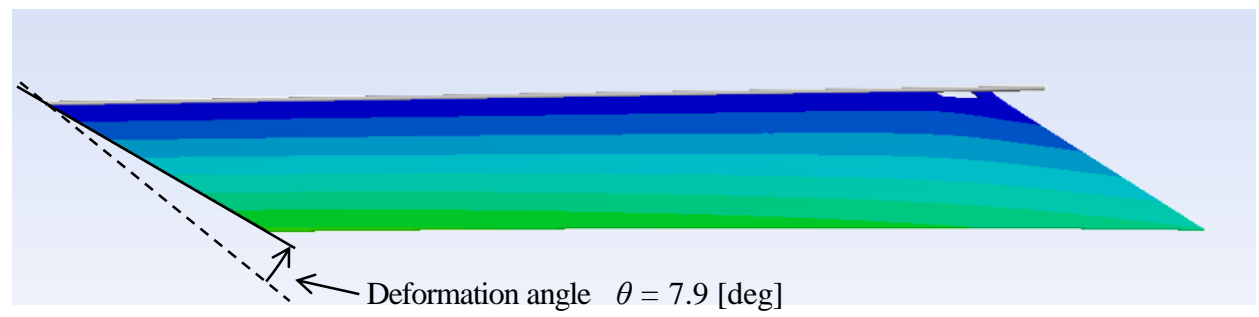

(b) Deformation of Nodus wing (Base) $(\alpha=30 \mathrm{deg})$

Fig. 8 Deformation of the nodus wings on gliding flight in case of $U=3 \mathrm{~m} / \mathrm{s}$ and $a=30 \mathrm{deg}$. The colors on wing models show the contour of displacement of the membrane from undeformed model, and dashed line shows the location of undeformed model. In (a) nodus wing (center), the deformation in tip side from nodus is larger than in base side. In (b) nodus wing (base), the membrane is deformed in widely area.

Table 3 Analytical results of deformation angle of wing on gliding flight in case of $U=3 \mathrm{~m} / \mathrm{s}$

\begin{tabular}{|c|c|c|c|c|c|c|c|}
\hline \multirow{2}{*}{\multicolumn{2}{|c|}{$\begin{array}{l}\text { Flow velocity } \\
\qquad U=3 \mathrm{~m} / \mathrm{s}\end{array}$}} & \multicolumn{6}{|c|}{ Attack angle $\alpha[\mathrm{deg}]$} \\
\hline & & 0 & 10 & 30 & 50 & 70 & 90 \\
\hline \multirow{2}{*}{$\begin{array}{l}\text { Deformation angle } \\
\qquad \theta[\mathrm{deg}]\end{array}$} & Nodus wing (Center) & 0.0 & 1.4 & 2.7 & 3.0 & 3.3 & 3.5 \\
\hline & Nodus wing (Base) & 0.0 & 3.7 & 7.9 & 8.8 & 9.6 & 10.3 \\
\hline
\end{tabular}


減少した。 これを揚抗比 L/D で比較すると，剛体翅の 4.36 に対し，結節翅（中央）は 4.46 と $2 \%$ 増加するが，結 節翅（根元）では 4.35 とほぼ変わらなかった。 このため, 滑空を考えた場合には変形量が小さい翅の方が高い揚 力を生成できるが, 適度な柔軟性を持たせると抗力が減少させ, 効率の良い滑空が行えるといえる. しかし, 柔 軟性が高すぎると揚力の減少が大きくなり, 滑空性能が下がってしまう.

図 9 に流入流速 $6 \mathrm{~m} / \mathrm{s}$ の場合の各迎え角における揚力係数・抗力係数の解析結果を示寸. 結節翅は剛体翅と比 べ抗力係数が減少し，揚力係数は小迎角で減少，大迎角で増大寸る傾向は流速 $3 \mathrm{~m} / \mathrm{s}$ の場合と同様であるが，よ り変化が顕著となった．結節翅（根元）では抗力係数が大きく減少し，迎え角 $50 \sim 70 \mathrm{deg}$ 付近では揚力係数の減 少が非常に緩やかになった. 図 10 に流入流速 $6 \mathrm{~m} / \mathrm{s}$, 迎え角 $30 \mathrm{deg}$ の時の結節翅の変形の様子を, 表 5 に各迎え 角における先端部の変形角度を示す. 流速 $3 \mathrm{~m} / \mathrm{s}$ の時と比べ変形角度が大きくなっており, 結節翅（中央）では 最大で $7.9 \mathrm{deg}$ の変形を，結節翅（根元）では最大で $19.6 \mathrm{deg}$ の変形を起こした. 特に結節翅（根元）では固定部 分が少ないために根元付近でも変形しており，これにより抗力係数の減少や揚力係数の変化が特に大きくなった ものと考えられる. 滑空飛翔を想定した迎え角 $10 \mathrm{deg}$ で $C_{\mathrm{L}}$ および $C_{\mathrm{D}}$ を比較する. 表 6 に揚力係数 $C_{\mathrm{L}}$ および抗 力係数 $C_{\mathrm{D}}$ と算出した揚抗比 $\mathrm{L} / \mathrm{D}$ を示寸. 剛体翅は $C_{\mathrm{L}}=0.686, C_{\mathrm{D}}=0.150$ であるのに対し, 結節翅（中央）は $C_{\mathrm{L}}$ $=0.514, C_{\mathrm{D}}=0.106$ とそれぞれ $25 \%, 30 \%$ 減少, 結節翅（根元）では $C_{\mathrm{L}}=0.264, C_{\mathrm{D}}=0.066$ と $60 \%$ 前後減少した. 揚抗比 L/D では, 剛体翅の 4.57 に対し, 結節翅（中央）は 4.85 と $6 \%$ 増加寸るが，結節翅（根元）では 4.00 と $13 \%$ も減少した。 この結果からも流速 $3 \mathrm{~m} / \mathrm{s}$ の場合と比べ変化が大きくなっていることがわかる.

以上の結果より, $10 \mathrm{deg}$ 程度の小迎角では変形しやすい翅は揚力係数と抗力係数が共に減少するため, 揚力で 考えると滑空時は変形しにくい翅の方が高い揚力を生成できる. しかしながら, トンボの翅を模擬した結節翅 (中 央）では根元付近が変形しにくいために揚力係数の過度な低下を防ぎつつ抗力係数を低減でき，揚抗比を上げる ことができると言える.

Table 4 Lift coefficient and drag coefficient on gliding flight in case of $U=3 \mathrm{~m} / \mathrm{s}$ and $a=10 \mathrm{deg}$

\begin{tabular}{c|c|c|c}
\hline$U=3 \mathrm{~m} / \mathrm{s}, a=10 \mathrm{deg}$ & Lift coefficient $C_{\mathrm{L}}$ & Drag coefficient $C_{\mathrm{D}}$ & Lift coefficient L/D \\
\hline Rigid wing & 0.685 & 0.157 & 4.36 \\
\hline Nodus wing (Center) & 0.615 & 0.138 & 4.46 \\
\hline Nodus wing (Base) & 0.431 & 0.099 & 4.35 \\
\hline
\end{tabular}

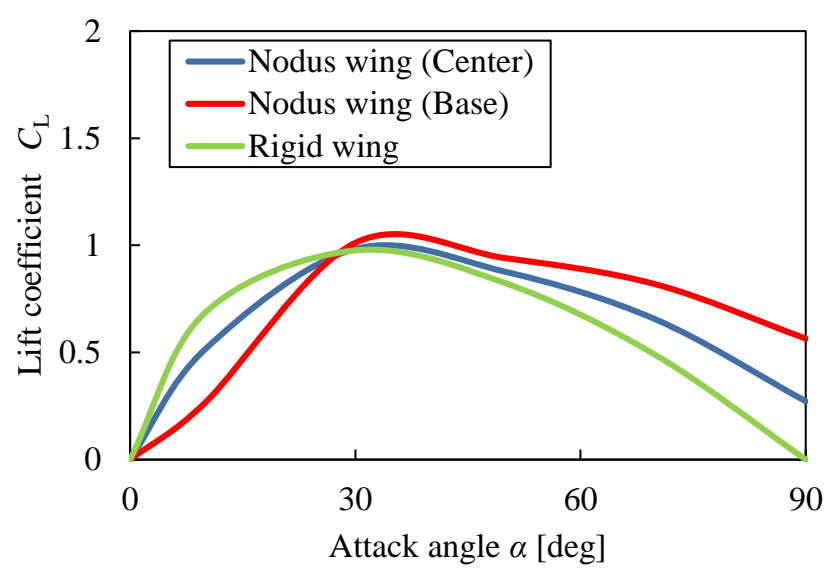

(a) Lift coefficient

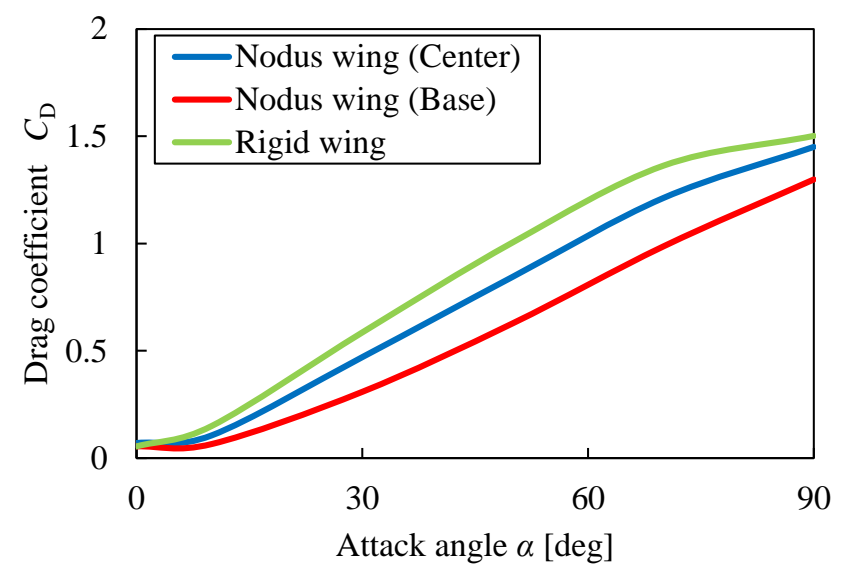

(b) Drag coefficient

Fig. 9 Analytical results of lift and thrust coefficient on gliding flight in case of $U=6 \mathrm{~m} / \mathrm{s}$. Changes of lift coefficient and drag coefficient of nodus wings are larger than the case of $U=3 \mathrm{~m} / \mathrm{s}$. In particular, the drag coefficient of nodus wing (base) is largely decreased when $a<30 \mathrm{deg}$. 


\section{Displacement}

\begin{tabular}{rl|l|l|l|l|l|l|l|l|l|l|l|l|}
\hline & & & & & & & & & & & & & \\
0.0 & 0.5 & 1.0 & 1.5 & 2.0 & 2.5 & 3.0 & $3.5[\mathrm{~mm}]$
\end{tabular}

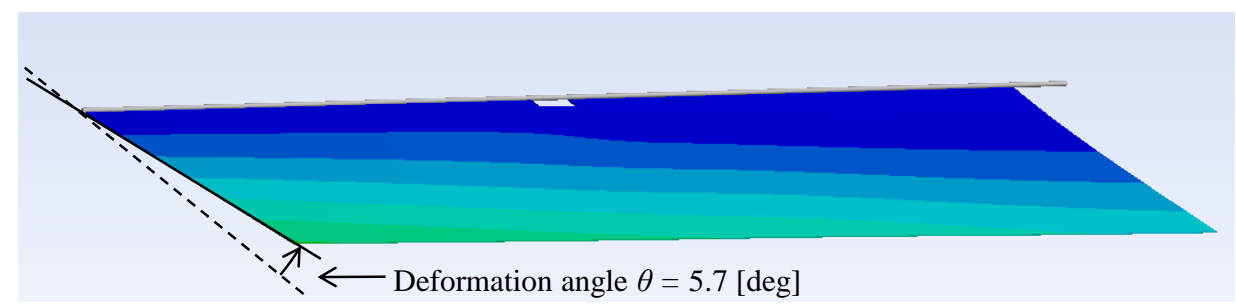

(a) Deformation of Nodus wing (Center) ( $\alpha=30 \mathrm{deg})$

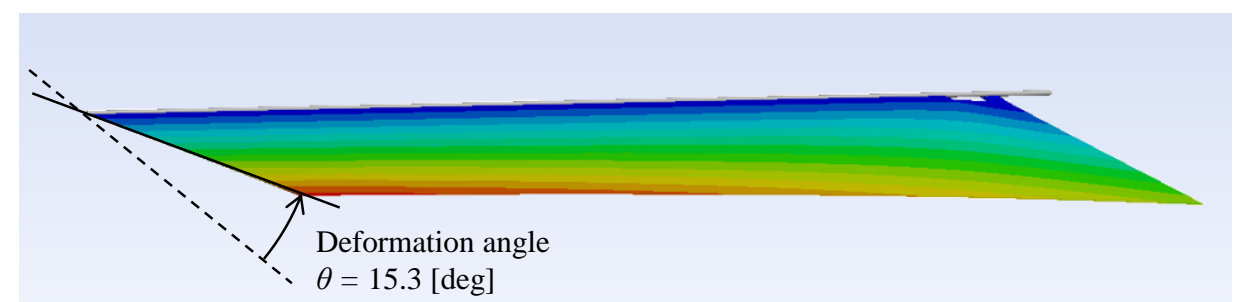

(b) Deformation of Nodus wing (Base) $(\alpha=30 \mathrm{deg})$

Fig. 10 Deformation of the nodus wings on gliding flight in case of $U=6 \mathrm{~m} / \mathrm{s}$ and $a=30 \mathrm{deg}$. The colors on wing models show the contour of displacement of the membrane from undeformed model, and dashed line shows the location of undeformed model. The deformation of nodus wings is larger than the case of $U=3 \mathrm{~m} / \mathrm{s}$.

Table 5 Analytical results of deformation angle of wing on gliding flight in case of $U=6 \mathrm{~m} / \mathrm{s}$

\begin{tabular}{c|c|c|c|c|c|c|c}
\hline \multicolumn{2}{c|}{$\begin{array}{c}\text { Altack angle } \alpha[\mathrm{deg}] \\
U=6 \mathrm{~m} / \mathrm{s}\end{array}$} & 0 & 10 & 30 & 50 & 70 & 90 \\
\cline { 2 - 8 } & Nodus wing (Center) & 0.0 & 3.1 & 5.7 & 6.3 & 7.1 & 7.9 \\
\hline \multirow{2}{*}{$\begin{array}{c}\text { Deformation angle } \\
\theta[\mathrm{deg}]\end{array}$} & Nodus wing (Base) & 0.0 & 6.3 & 15.3 & 15.8 & 17.6 & 19.6 \\
\cline { 2 - 8 }
\end{tabular}

Table 6 Lift coefficient and drag coefficient on gliding flight in case of $U=6 \mathrm{~m} / \mathrm{s}$ and $a=10 \mathrm{deg}$

\begin{tabular}{c|c|c|c}
\hline$U=6 \mathrm{~m} / \mathrm{s}, a=10 \mathrm{deg}$ & Lift coefficient $C_{\mathrm{L}}$ & Drag coefficient $C_{\mathrm{D}}$ & Lift-drag ratio L/D \\
\hline Rigid wing & 0.686 & 0.150 & 4.57 \\
\hline Nodus wing (Center) & 0.514 & 0.106 & 4.85 \\
\hline Nodus wing (Base) & 0.264 & 0.066 & 4.00 \\
\hline
\end{tabular}

\section{$3 \cdot 2$ 羽ばたき時の解析結果}

図 11 に羽ばたき 1 周期の間に生じる揚力・抗力の解析結果を示す. 横軸は羽ばたき 1 周期を示しており，打ち 下ろし始めを 0 ，打ち上げ終わりを 1 としている．揚力の值を見ると，剛体翅と比べ結節翅は全体が右にシフト したようなグラフとなっているが, 全体の傾向に大きな差は見られない. 羽ばたき 1 周期の平均值で比較すると, 剛体翅が $6.02 \mathrm{mN}$ であるのに対し結節翅（中央）が $6.39 \mathrm{mN}$ ，結節翅（根元）が $6.15 \mathrm{mN}$ と大きな変化は見られ なかった。一方，抗力の值を見ると結節翅では打ち下ろし中に生じる抗力が剛体翅と比較して大きく低減してお り，特に結節翅（根元）でその割合が大きい. しかし，打ち上げ中の負の抗力，つまり推力については全ての翅 モデルでほぼ同じ值を示した。羽ばたき 1 周期の平均值で比較すると，剛体翅が $3.45 \mathrm{mN}$ であのに対し，結節 翅（中央）で $1.90 \mathrm{mN}$ と $45 \%$ 減少，結節翅（根元）では $0.69 \mathrm{mN}$ と $80 \%$ も減少した. この結果から，結節翅は打 
ち下ろし中に発生する抗力を低減させる効果があると言える. また，本モデルはトンボの翅と異なり四角形状と したため, 翅が上もしくは下にある場合に前縁部が主流に対して斜めとなり根元側でデルタ翼の先端のようにな っている. しかしながら，羽ばたき時の揚力および抗力は主に打ち下ろし中と打ち上げ中に発生しており，この 時は翅に対して流入方向は斜めになっていないため, トンボの翅と異なるデルタ翼のような特性は羽ばたきでは 影響していないと考えられる.

図 12 に結節翅（中央）の羽ばたき中の翅の変形の様子を，図 13 に結節翅（根元）の変形の様子を表わした図 を示寸，それぞれ，左上の図から左下の図（(a)〜(c)）にかけて打ち下ろしを，右下の図から右上の図（(d)（f)） にかけて打ち上げを示している，翅は羽ばたき運動に応じて変形を起こし，特に先端部で大きな変形をしている ことが確認できる. 変形は打ち上げおよび打ち下ろしの切り返し時で最も大きくなり, 結節翅 (中央) では最大 で先端部が $12 \mathrm{deg}$ の変形を, 結節翅 (根元) では最大で $41 \mathrm{deg}$ の変形を起こした.ここで, 打ち下ろし中の翅 (図 12(b), 図 13(b)）を見ると, 翅が変形することで先端部付近が水平に近い状態となっている. 今回は羽ばたき平 面角を $60 \mathrm{deg}$ としたため, 変形しなければ翅は流れに対して $30 \mathrm{deg}$ の角度を持つことになるが, 結節翅は変形寸 ることでその角度がより浅くなっている. これにより, 打ち下ろし中の流れ方向の抵抗が小さくなり, 結果とし て抗力が低減したものと考えられる。次に打ち上げを見ると，打ち上げ中の翅（図 12(e), 図 13(e)）は打ち下ろ し時と比べ変形が小さいことがわかる．本解析では前進飛翔を仮定して前方（図の左側）から一様流を流してい るため, 打ち下ろし時は翅の動きが流れに対して拮抗するのに対し, 打ち上げ中は翅の動きが流れと同じ方向と なる．そのため，打ち上げ中は翅に流入する相対的な流速が低下寸る．翅の変形に対して影響が大きい先端部付 近で考えると, 打ち下ろし時の流入流速が $7.4 \mathrm{~m} / \mathrm{s}$ となるのに対し, 打ち上げ時では $4.8 \mathrm{~m} / \mathrm{s}$ となり, 流入流速に 1.5 倍以上の差がある. そのため, 打ち下ろし時と比べ打ち上げ時では翅に加わる圧力（動圧）が減少し, 変形量 が小さくなった．また，翅に対する流入迎え角も先端部で打ち下ろし時に $69 \mathrm{deg}$, 打ち上げ時に $56 \mathrm{deg}$ と打ち上 げ時の方が小さく, これも打ち上げ時の変形量が小さくなることに寄与していると考えられる. これにより，打 ち上げ中は翅が変形せず，打ち上げ中に発生する推力は結節翅でも剛体翅と同様の值を示したと考えられる. 以 上の結果より，トンボの前進飛翔（羽ばたき平面角=60 deg）の場合には羽ばたき時に翅が変形することで特に打 ち下ろし時の抗力が低減し, より前進しやすくなるものと考えられる.

滑空時には翅は変形しにくいほど揚力係数が大きく, 羽ばたき時には翅が変形するほど打ち下ろし時の抗力を 低減できる，このことから，トンボのように滑空と羽ばたきの両方の飛翔を行う MAV を設計するためには，人 工翅の柔軟性を適切に設定する必要がある. 本解析で用いた翅モデルの中では, トンボの翅を模擬した結節翅 (中 央）は剛体翅と比べ滑空時の揚抗比を $2 \%$ 増加させている $(U=3 \mathrm{~m} / \mathrm{s}$ 時). また, 羽ばたき時の抗力を $45 \%$ 大き

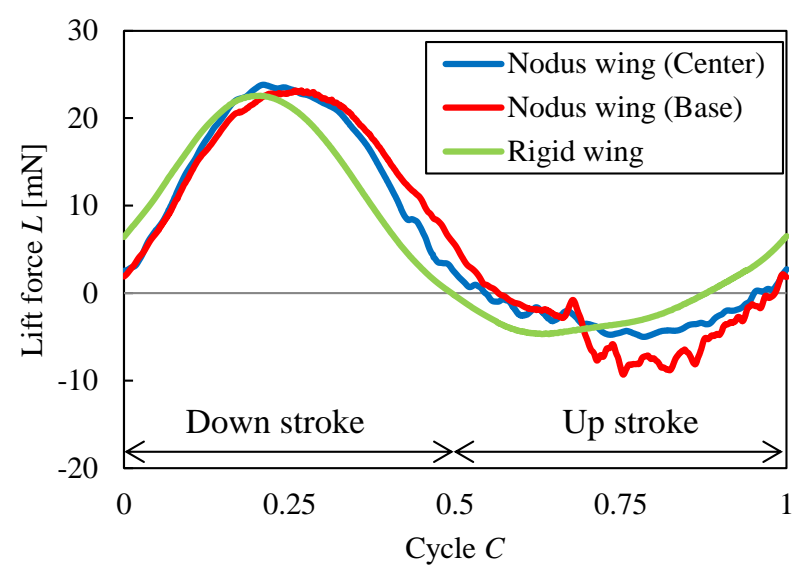

(a) Lift force

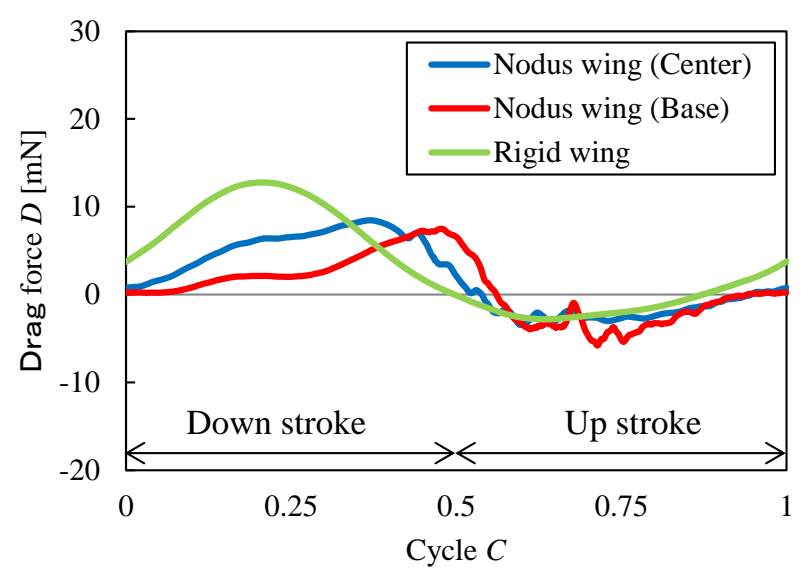

(b) Drag force

Fig. 11 Analytical results of lift and thrust force on flapping flight. These figures show one cycle of flapping from downstroke to upstroke. Lift force is almost same between nodus wings and rigid wing. Nodus wings decrease drag force generated during downstroke. On the other hands, nodus wings do not decrease thrust force (negative drag force) generated during upstroke. 


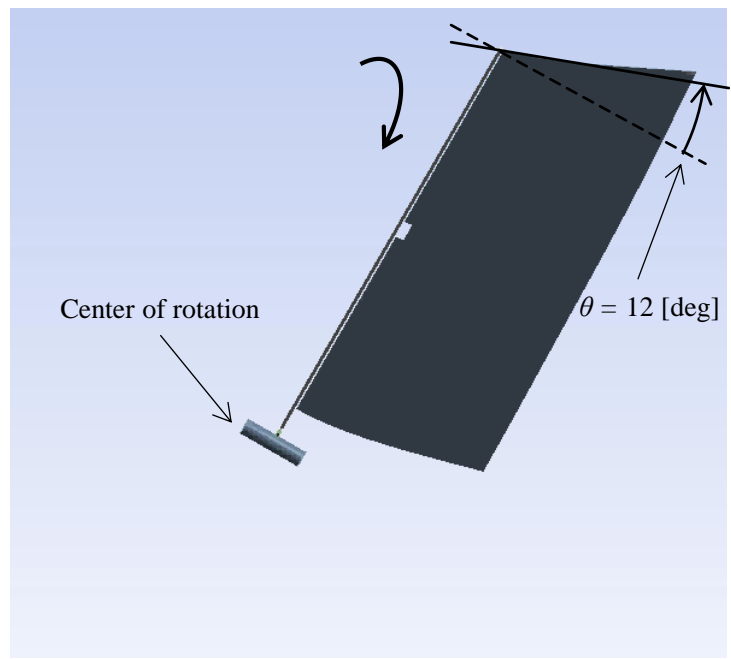

(a) Turning to down stroke

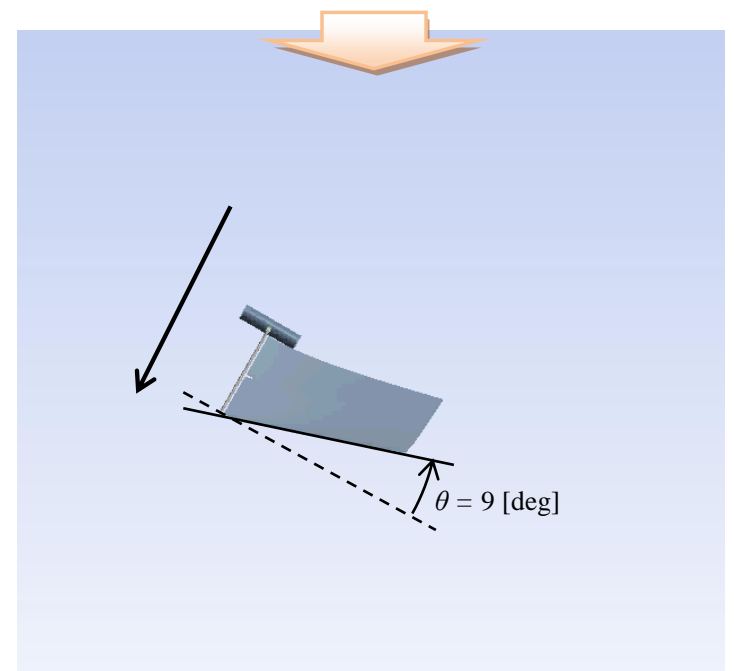

(b) During down stroke

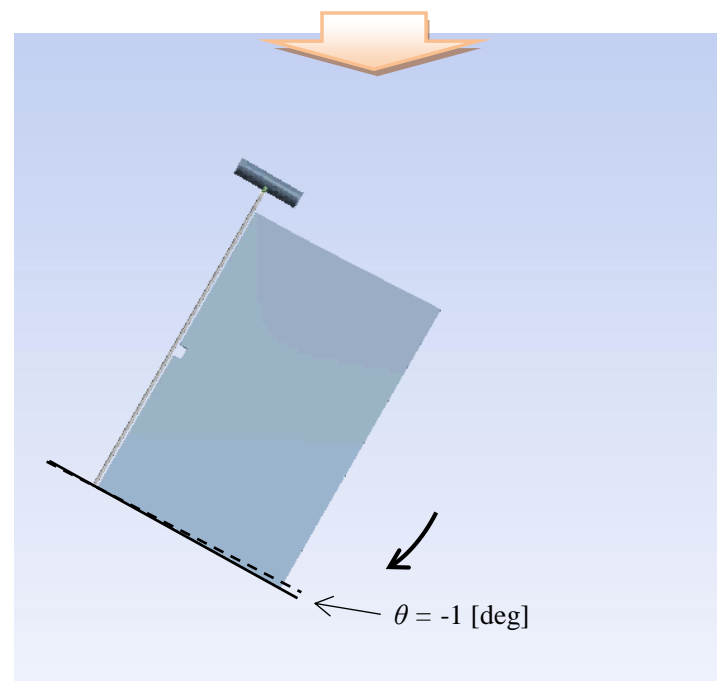

(c) End of down stroke

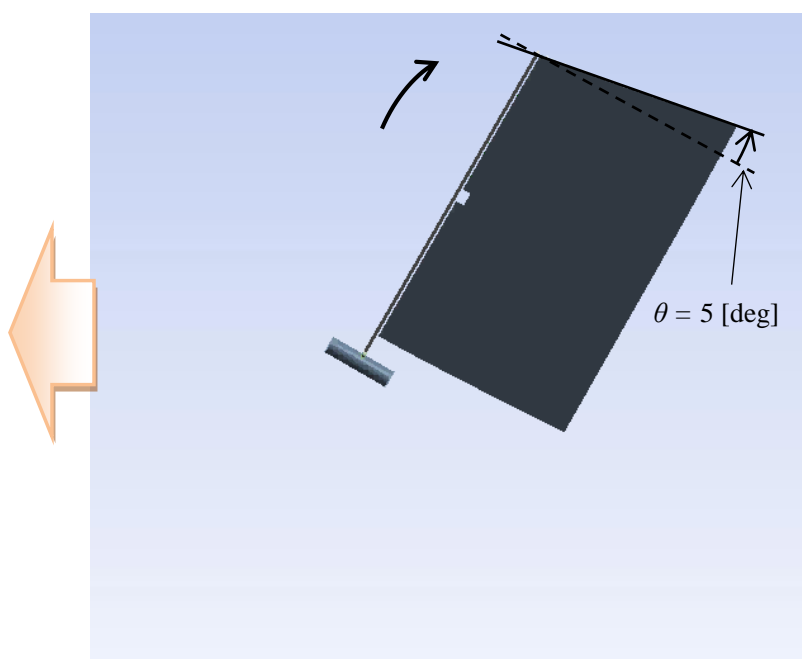

(f) End of up stroke

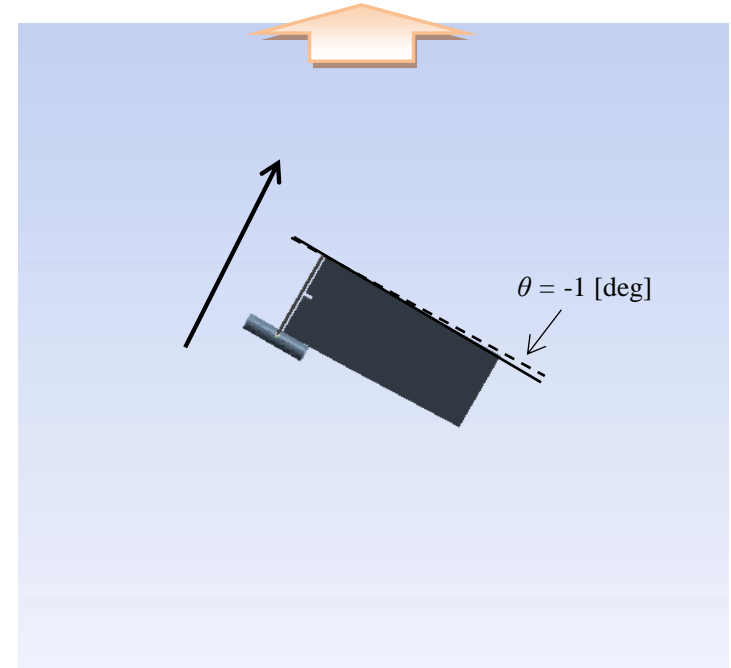

(e) During up stroke

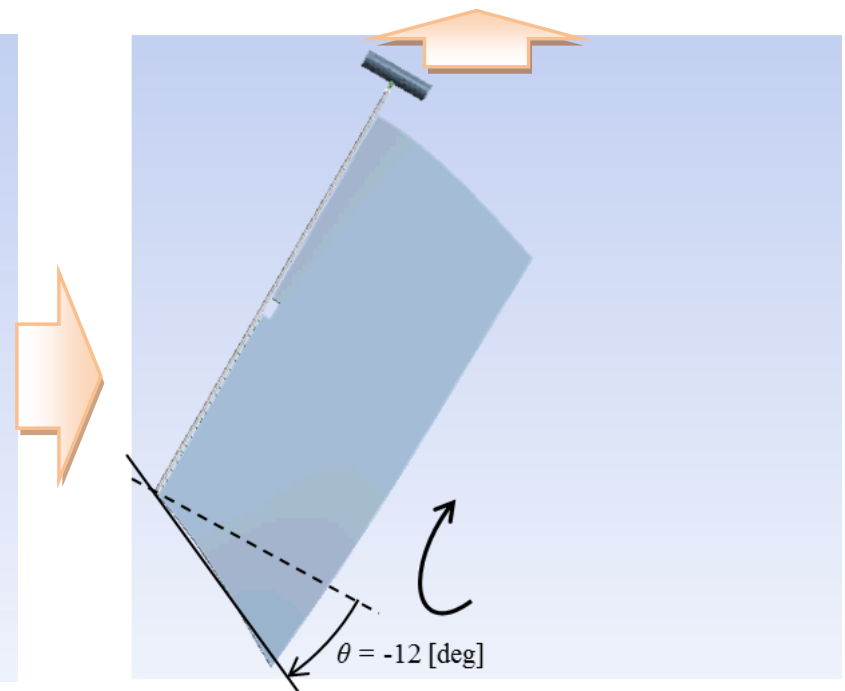

(d) Turning to up stroke

Fig. 12 Deformation of Nodus wing (Center) in one cycle of flapping. During down stroke (b), the nodus wing is deformed. On the other hands, during up stroke (e), the deformation of the nodus wing is very little. Therefore, the nodus wing decreases drag force during down stroke without decreasing thrust force during up stroke. 


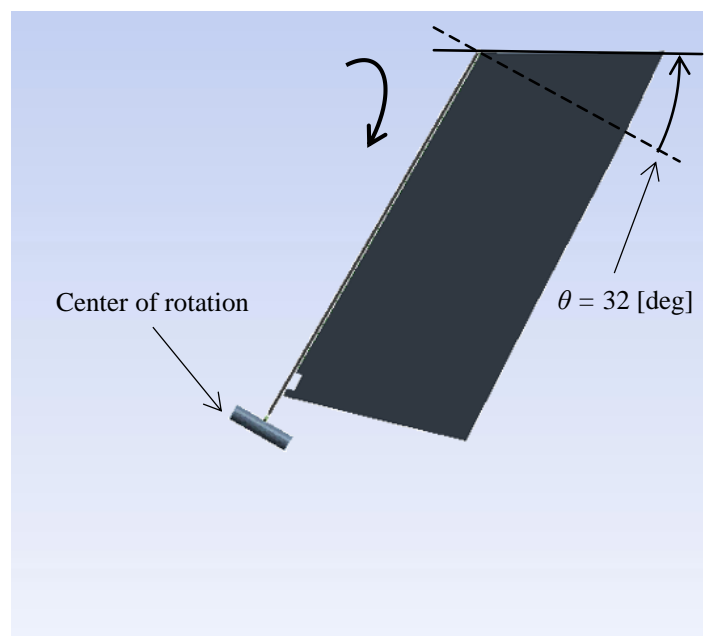

(a) Turning to down stroke

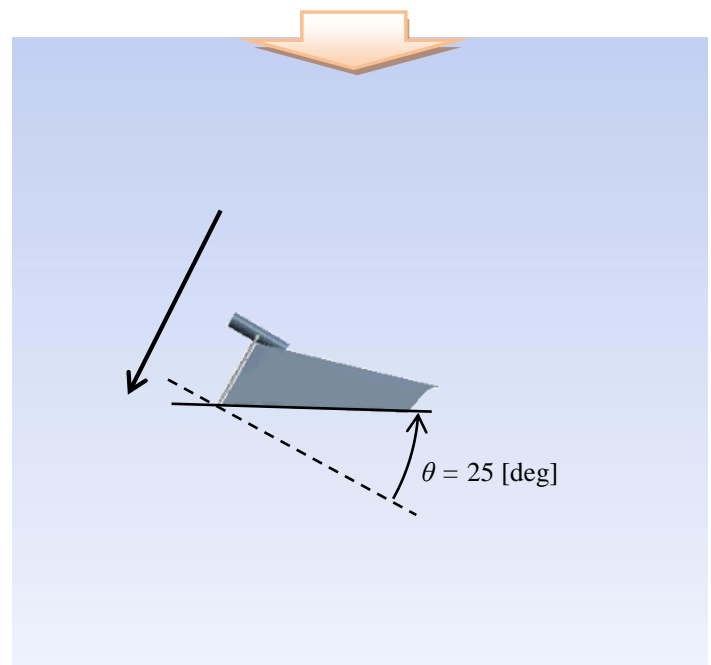

(b) During down stroke

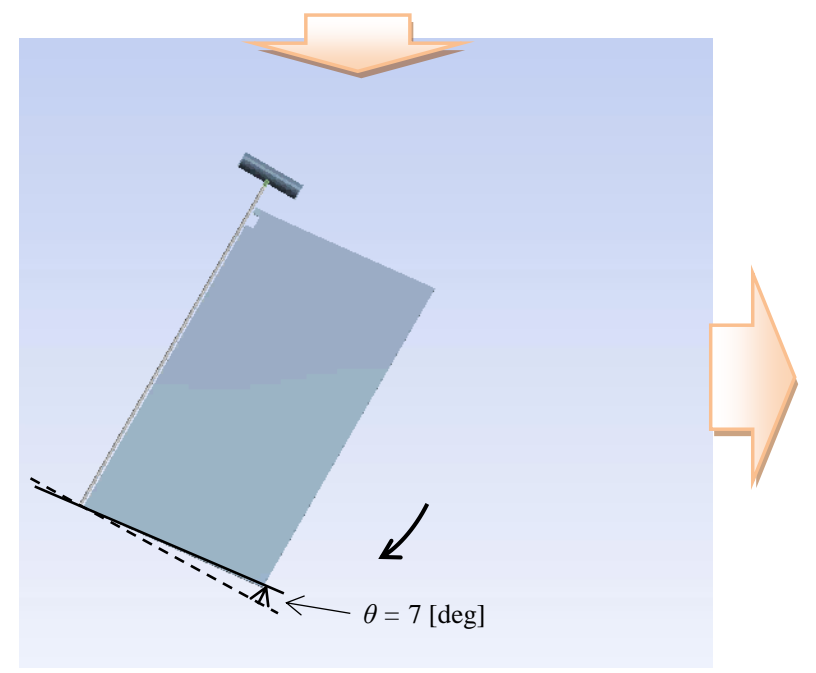

(c) End of down stroke

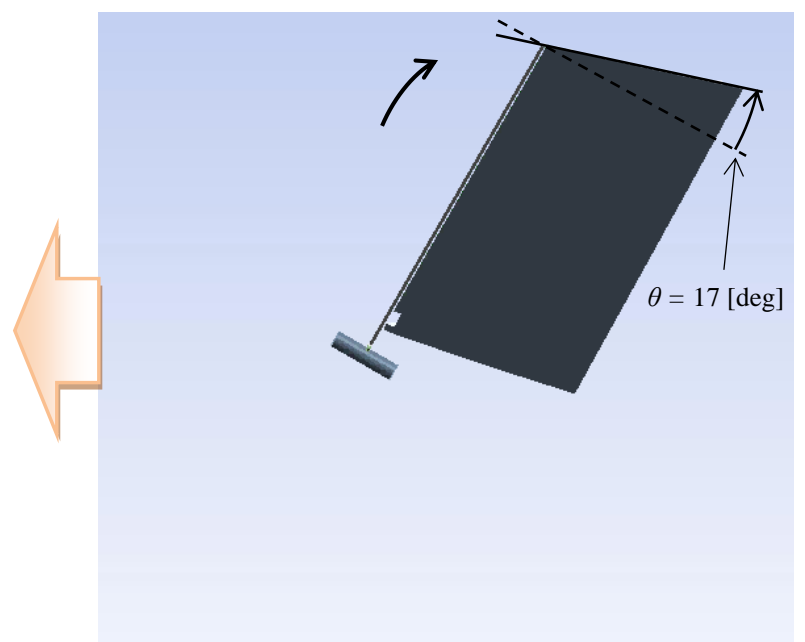

(f) End of up stroke

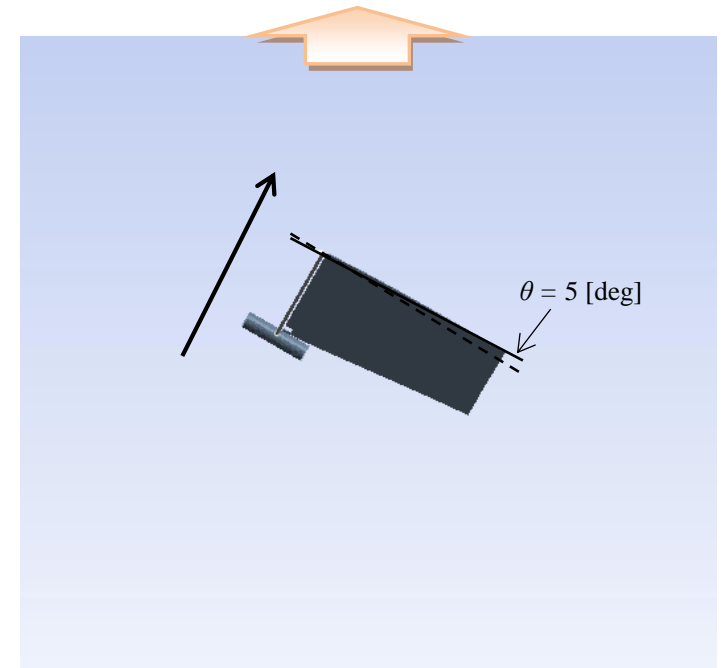

(e) During up stroke

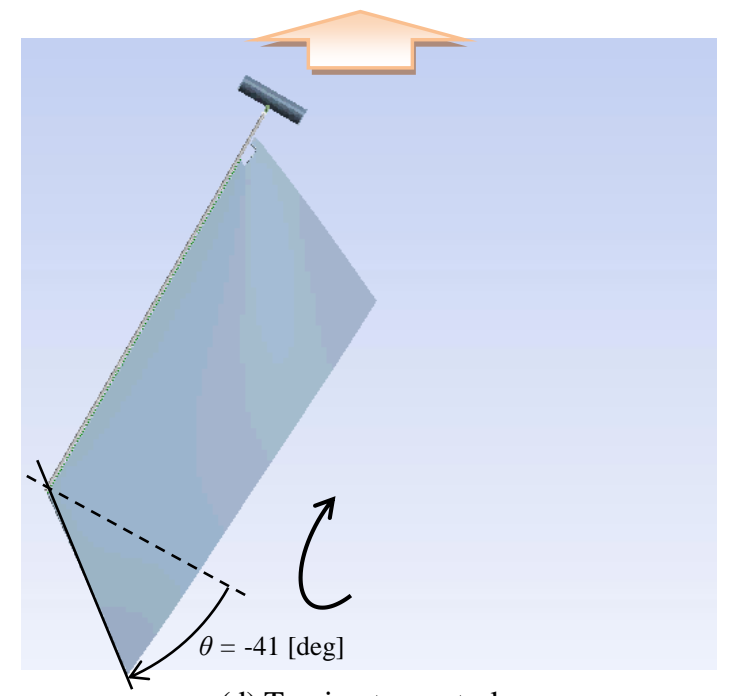

(d) Turning to up stroke

Fig. 13 Deformation of Nodus wing (Base) in one cycle of flapping. The deformation is larger than that of nodus wing (center). During down stroke (b), the deformation angle in tip of the wing is $25 \mathrm{deg}$, and therefore the tip side of nodus wing (base) is nearly-horizontal. 
く減少させている．これは，結節により先端側が変形しや寸く，根元側が変形しにくい構造のためである．この ことから，先端側は羽ばたきに，根元側は滑空に適していると言える．このように，1 つの翅で柔軟性が異なる 部分を持つことで滑空と羽ばたきの両方に適した性能とすることができる. また，羽ばたきは円弧運動となり先 端部の速度が速くなるため羽ばたきでは先端部の方が重要であると考えられることから，トンボの翅の結節によ る先端部の変形は理に適っていると言える. 以上のことから, トンボ型 MAV に搭載する人工翅には, 結節構造 を模擬して根元側を変形しにくく，先端側を変形しや寸くした構造が望ましいと言える.

なお，本解析の結果では抗力の平均が正の值，つまり推力としては負の值となっているが，これは本解析モデ ルではフェザリング運動を考慮していないためと考えられる。フェザリング運動は羽ばたき時の迎え角を変化さ せるため，今後はこの効果も含めたより詳細な検討が必要であろう.

\section{4. 結}

本研究では, トンボ型 MAV に最適な翅を作製することを目指し，流体構造連成解析によりトンボの翅の結節 による変形を模擬した結節翅モデルを用いて空力特性について検討した. 得られた知見を以下に示す.

（1）滑空時の空力特性では，結節翅は剛体翅と比べ抗力係数は全ての迎え角において減少し，揚力係数は迎え 角が小さい時は減少，迎え角が大きい時は増大寸る．また，変形しや寸い翅であるほど揚・抗力係数は大 きく変化する. 滑空を想定した迎え角 $10 \mathrm{deg}$ では結節翅（中央）は剛体翅と比べ揚抗比が増加するが，結 節翅（根元）は揚力係数の減少が顕著となり揚抗比が低下寸る.

（2）前進飛翔（羽ばたき平面角 $60 \mathrm{deg}$ ）の羽ばたきでは, 結節翅では打ち下ろし中に生じる抗力が大きく減少 する. これは打ち下ろし時には流れに対して拮抗する方向に翅が動き, 大きな変形を起こすことで流れに 対して翅の角度が浅くなり，抵抗の流れ方向成分が減少したためである.

（3）打ち上げ中に生じる推力は変形のしやすさに関わらずほぼ一定となる.これは，打ち上げ時には流れと同 じ方向に翅が動くため翅に対して相対的に風速が低下し，翅の変形が小さくなったためである.

（4）トンボの翅を模擬した結節翅（中央）は根元側が変形しにくく，先端側が変形しや寸い構造とすることで 滑空時の揚力係数の減少を抑えたまま羽ばたき時の抗力を減少させることができる. 結節により 1 つの翅 で柔軟性が異なる部分を持たせた結節翅は，滑空と羽ばたきを両方行うトンボ型 MAV に適している.

\section{文献}

Azuma, A. and Watanabe, T., Flight performance of a dragonfly, The Journal of experimental biology, Vol.137 (1988), pp.221-252.

Chen, J. S., Chen, J. Y. and Chou, Y. F., On the natural frequencies and mode shapes of dragonfly wings, Journal of Sound and Vibration, Vol.313 (2008), pp.643-654.

Dickinson, M. H., Lehmann, F. O. and Sane, S. P., Wing rotation and the aerodynamic basis of insect flight, Science, Vol.284 (1999), pp.1954-1960.

藤井賢一, 大熊政明, トンボの羽構造に関する構造動力学研究, Dynamics and Design Conference (2004), pp.427-1-427-6.

橋本巨, 石本早霧, 昆虫の飛翔筋をモデルとしたバイオニック・デザイン (第 1 報, 翅の振動メカニズム), 日本 機械学会論文集 C 編, Vol.63, No.607 (1997), pp.723-731.

伊賀厚介, 橋本巨, トンボの羽ばたきを模倣した MAV の開発 飛翔映像撮影と非定常状態の可視化, 2007 年度年 次大会講演論文集, No.6 (2007), pp.97-98.

Jongerius, S. R. and Lentink, D., Structural analysis of a dragonfly wing, Experimental Mechanics, Vol.50, Issue 9 (2010), pp.1323-1334.

Naka, H. and Hashimoto, H., Effects of deformation and vibration characteristics of wings on flapping flight, Mechanical Engineering Journal, Vol.2, No.1 (2015), DOI: 10.1299/mej.14-00262. 
Nakata, T. and Liu, H., A fluid-structure interaction model of insect flight with flexible wings, Journal of Computational Physics, Vol.231, Issue 4 (2012), pp.1822-1847.

酒井風馬, 橋本巨, トンボの翅の断面形状と揚力生成の関係, 第 14 回機素潤滑設計部門講演会講演論文集, No.14 (2014), pp.15-16.

Sunada, S., Zeng, L. and Kawachi, K., The relationship between dragonfly wing structure and torsional deformation, Journal of Theoretical Biology, Vol.193, Issue 1 (1998), pp.39-45.

\section{References}

Azuma, A. and Watanabe, T., Flight performance of a dragonfly, The Journal of experimental biology, Vol.137 (1988), pp.221-252.

Chen, J. S., Chen, J. Y. and Chou, Y. F., On the natural frequencies and mode shapes of dragonfly wings, Journal of Sound and Vibration, Vol.313 (2008), pp.643-654.

Dickinson, M. H., Lehmann, F. O. and Sane, S. P., Wing rotation and the aerodynamic basis of insect flight, Science, Vol.284 (1999), pp.1954-1960.

Fujii, Y. and Okuma, M., A research of dragonfly wing on structural dynamics, Dynamics and Design Conference (2004), pp.427-1-427-6 (in Japanese).

Hashimoto, H. and Ishimoto, S., Bionic design based on modelling of flight muscle of insects : 1st report vibration mechanism of wing, Transactions of the Japan Society of Mechanical Engineers, Series C, Vol.63, No.607 (1997), pp.723-731 (in Japanese).

Iga, K. and Hashimoto, H., Development for MAV of dragonfly's wing motion: flight motion photographs and visualization on unstationary state, JSME annual meeting, No.6 (2007), pp.97-98 (in Japanese).

Jongerius, S. R. and Lentink, D., Structural analysis of a dragonfly wing, Experimental Mechanics, Vol.50, Issue 9 (2010), pp.1323-1334.

Naka, H. and Hashimoto, H., Effects of deformation and vibration characteristics of wings on flapping flight, Mechanical Engineering Journal, Vol.2, No.1 (2015), DOI: 10.1299/mej.14-00262.

Nakata, T. and Liu, H., A fluid-structure interaction model of insect flight with flexible wings, Journal of Computational Physics, Vol.231, Issue 4 (2012), pp.1822-1847.

Sakai, F. and Hashimoto, H., Relationship between lift and cross-sectional wing shape of dragonflies, The 14th. Machine Design and Tribology Division Meeting in JSME, No.14 (2014), pp.15-16 (in Japanese).

Sunada, S., Zeng, L. and Kawachi, K., The relationship between dragonfly wing structure and torsional deformation, Journal of Theoretical Biology, Vol.193, Issue 1 (1998), pp.39-45. 